

\section{DATE DUE}

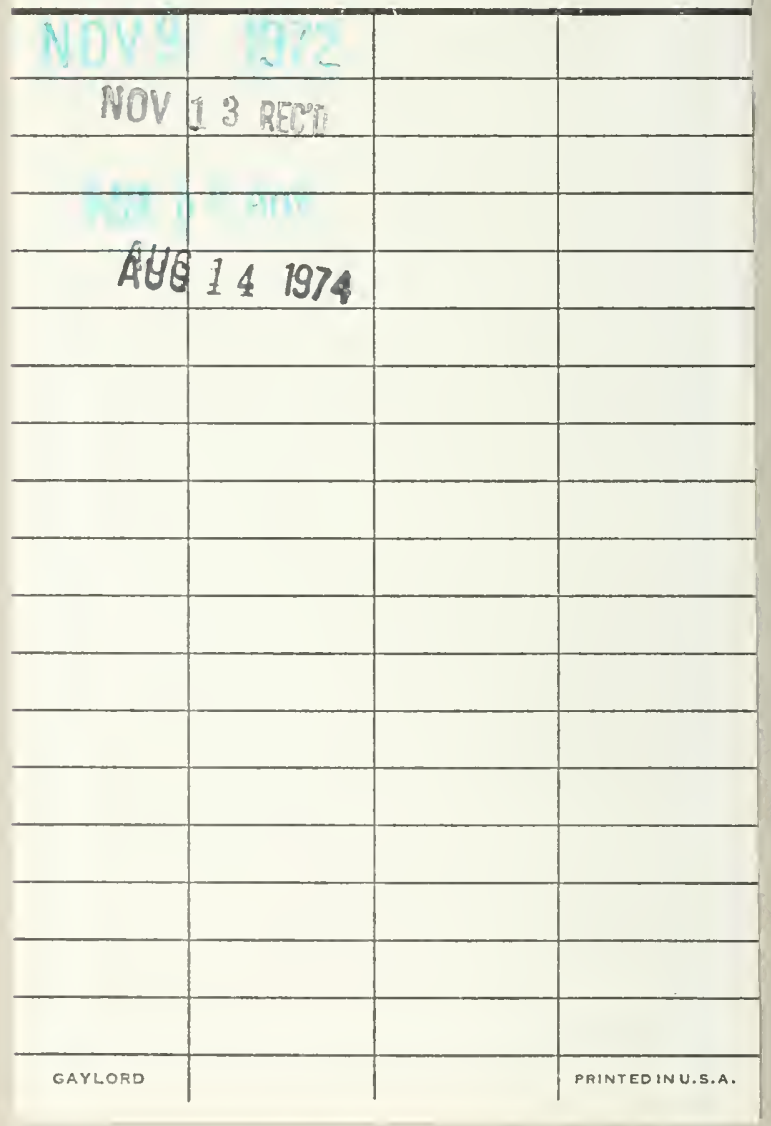




\section{BIOMEDICAL LIBRARY \\ UNIVERSITY OF CALIFORNIA, SAN DIEGO}

LA JOLLA, CALIFORNIA

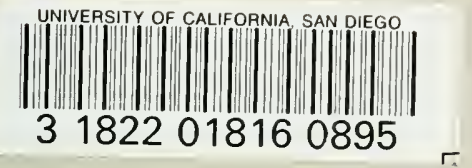





REPRINT No.

UNIVERSITY OF LONDON

GALTON LABORATORY FOR NATIONAL EUGENICS

EUGENICS LABORATORY LECTURE SERIES, VI

\section{NATURE AND NURTURE}

THE PROBLEM OF THE FUTURE

BY

KARL PEARSON, F.R.S.

A Presidential Address to the Social and Political Education Lengue, April 28, 1910

SECOND EDITION

LONDON

DULAU \& CO., LTn., 37 SOHO SQUARE, W.

19I3

- Price One Shilling net 


\section{UNIVERSITY OF LONDON}

\section{The Francis Galton Laboratory for National Eugenics}

This l-aboratory was founded by Sir FrANcrs GalTon, and is under thit direction of Professor KARL PEARSON, F.R.S.

Assistants: David Hzron, M.A., D.Sc., Ethel M. Elderton, Amy Barring, ION. Hon. Sec.: H. GERTIUDE JONES.

National Eugenics is the study' of agencies under socnal control, that may improut or impair the racial qualities of future generations, either physically or mentally.

It was the intention of the Founder, that the Laboratory should serve (i) as a storehouse of statistical material bearing on the mental and physical condition in man, and the relation of these conditions to inheritance and environment (ii) as a centre for the publication or other form of distribution of informatio concerning National Eugenics; (iii) as a school for training and as isting research workers in the special problems of Eugenics.

Short courses are provided for those who are engaged in social, medical, of anthropometric work.

\section{UNIVERSITY COLLEGE, LONDON}

\section{The Biometric Laboratory.}

This Laboratory is intended to forward the statistical study of Biological Problems. Director: KarL PeARSON, F.R.S.

Assistants: Julia Bell, M.A., IIErbert G. Soper, M.A., Eveline Y Thomson. Benington Studentship in Craniometry: KatuleEN T. RYLey.

Until the phenomena of any branch of knowledge have becn swbjected to measure ment and number, it cannot assume the slatus and di nity of a science.-Franci. GaLTON:

The Laboratory is assisted by a grant from the Worshipful Company o Drapers. It provides a complete training in statistical $m$ tl orl and a ssists researc workers engaged on biometric problems.

Communications for either Laboratory should he addressed to Universit) College, - I.ondon, WT.C. 


\title{
Nature and Nurture.
}

\section{The Problem of the Future}

\author{
A PRESIDENTIAL ADDRESS
}

DELIVERED BY

KARL PEARSON, F.R.S.

AT THE ANNUAL MEETING OF THE SOCIAL AND POLITICAL EDUCATION LEAGUE April 28, I9IO

WITH TWO PLATES OF PEDIGREES

SECOND EDITION

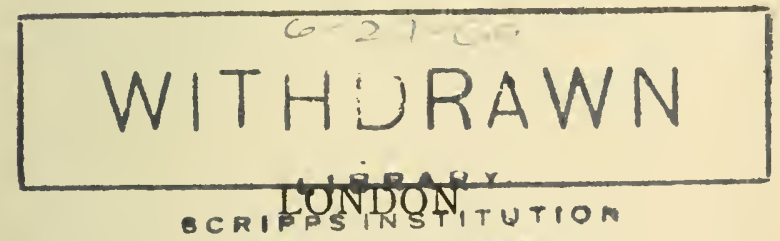

PUBLISHED BY ODELAURAND CO., LTD. UNIVERSITY DF CAI.IFDRNIA 37 SOHQ SQNAARE, IROHDON 
Accurate and minute measurement seems to the non-scientific imagination a less lofty and dignified work than looking for something new. But nearly all the grandest discoveries of science have been but the rewards of accurate measurement and patient, long-continued labour in the minute sifting of numerical results.-LORD KELVIN.

Eugenics, Laboratory Lecture Series III : The Relative Strength of Nurture and Nature, contains a fuller statistical treatment of the topic of the present lecture. 


\section{NATURE AND NURTURE THE PROBLEM OF THE FUTURE}

When I was requested last year to take up the very honourable office of President of the Social and Political Education League, my thoughts naturally turned on how I could best fulfil my function as your annual lecturer. My reminiscences of the League extended back to thirty years ago, when, fresh from the University, I was a member and a frequent lecturer at the various workingmen's clubs, political, social, and occasionally revolutionary, which then abounded in London. Looking back on that period now, it still appears to me one of very great intellectual activity. Clifford was only just dead, Huxley was still in the fighting line, Karl Marx was finishing Das Kapital and organizing outpost skirmishes of the revolutionary party. It was possible to be present, if not to assist, at the birth of the Social Democratic Federation; or, again, to hear a little later the mournful farewell of the Brotherhood of the Common Life, when a section of their comrades preferred the Fabian policy of discussing to that of practising socialism. Much has survived from that day, something has gone under. But it still seems to me to have been a period of exceptional intellectual activity and of very widespread enthusiasms. The working man wanted to know about Darwin, he wanted to know about Lassalle, and he wanted to discover the bearing of the scientific and the theological, or, if you will, anti-theological, thought of the day on his own social and 
political problems. He might not accept Arnold Toynbee's solution, but on the whole he gave him a respectful hearing, and he was exceedingly courteous to most of us, even when we approached him, as I very frankly confess I did, without any experience of his life or its possibilities.

Looking back on that period, I still think it was a very great achievement of Seeley to have seen all the many excellent results which must flow from bringing young men, full of the new ideas and theories, into touch with another class just awakening to the conception that this renascence had possibly some bearing on their lives also. Yet, regarding the matter a little more closely-and speaking only for myself, for whom alone I am in a position to judge-I feel sure that the balance of good was in the knowledge I gained, and not in the ideas and theories I did my best to impart to those working-class audiences.

Speaking still for myself only, let me tell you what I gradually learnt from those carly meetings with working inen at lectures and in discussions. First, I became impressed with the fact of the real existence of great social problems, that the position of labour, the changing status of women, and the relation of the child to the State were bound to be the great national questions of the near future. You will say that these things are the commonplaces of to-day. Indeed they are, but I was then as now a very slow thinker, and at the time of which I am speaking compulsory education was not universal, there was no labour party, and women were still content with drawing-room suffrage meetings, and entering the academic lecture-room by the backstairs. So much was positive knowledge. Secondly, I reached negative knowledge, perhaps the most valuable element of my education at the time. I slowly came to perceive that the solution 
of these problems would never be reached by verbal discussion; that the principles of evolution could not be profitably applied to human societies by popular lecturers or by discussion clubs; still less could sociological problems be solved by the methods of political argument, or of philosophical reasoning. Well, you will again tell me, that this is common knowledge. So, perhaps, it is, or shall I say, it very nearly is? For I picked up a journal termed the Sociological Review the other day, and the first article that attracted my attention was by a distinguished professor of philosophy, entitled 'National Degeneracy', and the problem was solved to the satisfaction of the professor in some ten pages of type, without a single figure, without a single sign that he had knowledge of the immense biological complexity of a question which for a true answer needs not verbal disquisition but an intensive study of heredity in man, of differential marriage rates, differential fertility, selective death-rates, to say nothing of immigration and emigration, and of the correlation of all these with the social and antisocial qualities of the several reproductive groups in the community. No, I think there are still some exceptions to the universality of this negative knowledge! Do we not still occasionally see the most fundamental problems of our national and social life settled without a single appeal to reliable data, or to reliable data properly interpreted, from the hustings, in our fitly termed parliament, or in the almost greater parliament of the press? Let us remember that these were the sources whence our working classes drew most of their knowledge, and that Seeley thought that we ought to be in a position to give them something better.

How ' better'? That was the question rapidly thrust 
on me from that contact with the worker in the early eighties. The problems that the working man was then specially interested in were, from the very nature of the case, sociological. He and I and everybody saw the grave social difficulties of our modern industrial state. But what contributions could we possibly make to their solution? We, the lecturers, were fresh from the universities, and the one thing which had formed no part of our training was an exact study of man. We had been trained to examine with the utmost care and minuteness, to reason only by aid of the most rigid mathematical analysis about all physical phenomena; we had been taught that in vital phenomena, endless patience, untiring observation, the finest instruments, are needful, if we are to learn the truth as to the plant and animal worlds. But as to man, the only science named after him was applied to the measurement of dry bones. We were left to the verbal discussion of undergraduate societies for our knowledge of man, and for the theories out of which we were to evolve 'something better' than mere talking could provide for the working man. One may reasonably suppose that this state of affairs has in the course of thirty years been radically altered at our universities; that nowadays every undergraduate is taught the broad facts as to heredity, fertility, and selection, and their bearing on the welfare of human societies. If it be so, then this League has much to give its audiences, which we in the eighties had not. If it be not so, then we need a new renascence-a renascence, not of learning, but of teaching, as the old renascence indeed was. That movement was a revolt of the students, who deserted the lecture-rooms of the old teachers and sought new masters; it was essentially a students' revolution which 
convulsed academic Europe at the end of the fifteenth century; and those youthful Humanists were apostles to the whole population. Many of you know better than I whether a new Humanism is wanted in our universities, and what chance a demand for knowledge of man would stand against the excitement raised by discussing a proposal to modify a football rule. Still I believe in youth, in spite of the fact that, or possibly because, I am getting old. If there is to be a reform in our academic teaching, I should have more hope of youth, enthusiastic and unpledged to the authorized, carrying it through than a series of Royal Commissions. Whatever be the case now, whatever may be the case in the future, I am certain that in the past the academic training was not such that it threw any light directly on the treatment of social problems. Indirectly we were taught to think by exact methods, indirectly we came to consider ourselves as units in a community-were it either school or college. But directly to reason by exact methods about ourselves or our fellow men as parts of a great social structure-the science of man-lay wholly outside the academic field. Social reform, political movements, national welfare, were not subjects for exact study, they were matters for opinion, for discussion, or for rhetoric, without preliminary academic training such as we demand in the physicist or the biologist. Here theory followed the codification of phenomena; there opinion justified itself in nine cases out of ten by a summary of those facts only which supported the prejudgement. If you think my criticism is harsh, I would ask you to study the evidence attached to the Report of almost any recent Royal Commission. You will find it a mere summary of the opinions of a few individuals who have 
been called as witnesses because they represented opposite views or because they had a popular reputation as authoritics. Should we expect to learn the truth about the influence of parental alcoholism on the offspring by taking the evidence of a brewer, a publican, the Secretary of the United Kingdom Alliance, and a fashionable medical consultant who has had to deal with extreme instances in a special social class? Is it not rather a case where we must use the careful methods of exact science? Hundreds of homes must be visited, hundreds of parents, alcoholic and non-alcoholic, must be observed and reported on; more than hundreds of children must be measured and weighed, their physique and their mentality must be recorded by medical officer and teacher, and then, what? Shall we know the answer to our problem? No, certainly not. We shall have the data from which an answer may be extracted, when and when only we use all the caution and refinement possible to modern statistical methods. To emphasize what I mean by this caution and refinement let me point out some of the difficulties involved in this very problem of alcoholism. Let us suppose that we have found out that the child death-rate of alcoholic mothers is higher than that of sober mothers--have we any right to infer that alcoholism leads to many child-deaths? It seems straightforward enough to make the inference, but yet note how terribly complex these problems are! We find that alcoholism of the mother is even more intimately associated with her employment than it is with the death-rate of the child. Is it possible, therefore, that employment of mothers, and not alcohol, is the source of this increased death-rate? No, we cannot stop there. The employment of women is associated with an ' unhealthy' trade 
in the father. Why? because he gets low wages in that trade. You might think, possibly, that an 'unhealthy' trade should mean high wages. Well, it does in one or two very exceptional instances, but in the bulk of cases it means this: that the mortality is high in that trade, because it can be followed by puny, unhealthy, and stupid men. Low wages are paid to such men. Low wages, due to poor physique and mentality of the father, are one of the chief causes of the mother's employment. All these are points which we can statistically demonstrate. Now what has become of our simple problem, the higher death-rate of the child associated with alcoholism in the mother? Poor physique in the father, a so-called unhealthy trade, low wages, employment of the mother, alcoholism in the mother, are all associated together. To which of these factors, or in what proportions to all of them, shall we attribute the increased death-rate in the offspring? Is it a toxic effect of alcohol in the mother, a toxic effect of ' unhealthy trade' of the father, or want of nutriment and space due to low wages? Is it absence of the mother owing to her employment, or is it carelessness owing to her alcoholism? Is it after all an hereditary effect due to the father's poor physique, or even to the mother's coming of a physically degenerate stock? Which of all these possible sources is the true origin of the increased death-rate, or is it due to combination of these and possibly of other factors? I do not say such problems cannot be solved. I think we shall solve them. But they need an analysis, a calculus, as complex as any which has been developed to deal with physical phenomena; they need as close a power of observation and as careful a record as any problem in biology. General theories of society are no use, verbal 
discussions are no use, philosophical reasoning is no use. We nced to observe, measure, and record, to analyse by the methods of exact science, before we can advance in our sociology, before we can aid our working classes to a true insight of the factors which make for or mar our national vigour.

That lesson was the experience I gained as a lecturer for this League some thirty years ago. It took me, as a slow thinker, several years to learn it, and very little return I made for that to me inestimable knowledge. Bricfly, this is what I learnt: I am endeavouring to help, where $\mathrm{I}$ am really ignorant. These men ask me as to the facts of human life and I reply with theory and dogma. The university has omitted the great essential for social work-a concrete study of man. We have yet to collect the data upon which such a study can be based-the very calculus by which it can be analysed has yet to be invented.

I am speaking of thirty years ago. It would be invidious to mention individual workers in this field during the past thirty years; but one name I will mention, that of Francis Galton, who in his papers of the decade centring round 1880 gave social workers the foundation on which the calculus of correlation has been finally established. Quietly also, and without our fully realizing it, masses of sociological data are now being officially collected and partially tabled. I refer to the medical inspection of school children by the county council education boards. The schedules drawn up, especially in the case of industrial school children, contain parental data often of the highest value-wages of father, rent, number of rooms, occupation of mother, number of living and dead children, health of parents, record of special diseases and disabilities, and much else of interest. Not only is this official infor- 
mation steadily increasing, so that it is growing more and more possible to grasp how the nation is constituted and how it reproduces itself, but many charitable organizations are learning that it is as fundamental to study the recipient as to aid him. Indeed, it will soon be recognized that without this primary study the organization of charity is futile. In this respect I would refer to the excellent work which has been done in Liverpool, Manchester, Birmingham, and, above all, Edinburgh. At present London stands very much behindhand in the production of statistical material available for sociological studies. London has been made too much the field for the clash of party; there is too much verbal and semipolitical discussion, too many strong individuals with already formed opinions, for charitable organizations to set to and quietly gather data in an unprejudiced manner. Yet that knowledge must be gained before useful work can be done by either state, municipality, or charity. I claim-not for the old sociology with its philosophical and verbal disquisitions-but for the new medico-social data and for the new calculus of correlation, a recognized place in science; a right to speak in the future with some authority in matters of social reform, and even on points of supreme national welfare. I believe that the day for acting merely on a consensus of opinion based on rhetorical or emotional appeal of a political or philanthropic character is passing by. IVe have to ascertain the nature of the action and reaction of social factors, before we can form opinion and settle definitely a social policy. You may assert that the employment of women should cease because such employment is associated with a higher child death-rate, but until you have carefully analysed how much is due to the associated alcoholism, how much to 
the employment itself resulting from such women having mentally and physically inferior husbands earning low wages, you cannot profitably attempt to discuss such a problem as the employment of women. Or, again, take the problem of crime; it has been asserted that crime is associated with certain forms of the head, and certain physical stigmata. Whole schools of criminology have arisen based solely on such assertions, and yet up to the present time no satisfactory treatment of crime is really possible, because there has been no scientific, investigation as to whether crime is correlated with any peculiar physical or mental characters; in reality nobody knows whether crime is associated with general degeneracy, whether it is a manifestation of certain hereditary qualities, or whether it is a product of environment or tradition. There is endless talk about crime and criminals, but hardly any one of the so-called criminologists has really worked on the only lines by which an adequate answer could be obtained to a great national problem. Or, again, let us take the problem of shortsightedness-an evil which is possibly on the increase in this country, and might become here as great a national detriment as it is to some of our neighbours. Is it due to inheritance and the modern cessation of that stringent selection in vision on which primitive races so much depend, or is it a product of living in towns with no distant horizon, or is it due to home environment, or to school environment, to increased reading, or to bad lighting? These are all questions, unsettled for want of data, and for want of an effective method of analysis. Nay, there is hardly any social problem of which the like cannot be said. Tuberculosis, insanity, alcoholism, employment of women, want of employment of men, town life, health 
of children, difficulties of degeneracy, questions of national fertility, all the bearings of charity, organized and unorganized, state help and state control, all these and many other sociological problems really await solution, and we cannot teach the people what is really for the welfare of the nation, because we ourselves do not know it at present. If you consider the evils which are associated with any of the problems I have referred to, you will see that not the only, but the main difficulty of remedying them lies in our ignorance of how much of the evil is due to environment and how much is due to heredity. Briefly, is murture or nature responsible? Is insanity the product of the strain of modern life, or is a constitutional weakness a necessary antecedent ? Do wretched homes produce degenerate stock, or degenerate stock wretched homes? Is unemployment the outcome of defective economic conditions, or the sign of the increasing survival of human wastage? Does the health of the children depend more on the physique of their parents or on their home environment? You may reply that these questions are insoluble; that social evils flow partly from one cause and partly from another. Can we be sure of that? Is that the way in which we have been taught to answer in our academic training a physical or a biological problem? What would you think of a physicist who told you that the position of the plumb-line depended partly on gravity and partly on the rotation of the earth? Would you not at once ask him to define quantitatively the relative influence of both factors? How is it possible to evolve a working policy for social reform if we do not know whether I per cent. or 90 per cent. of the observed evil is due to nurture? What breeder of cattle would be content to state that the defects of his 
herd were due in part to food and stallage, and in part to the character of his foundation stock and his choice of matings? Would he not endeavour to determine the limits and proportions of each factor?

But if we assume that any profitable result could flow from the vague answer that social evils are in part due to nurture and in part due to nature, have we ever acted upon this answer? Have we not for the last seventy to cighty years devised all our social reform on the conception that we had but to improve the environment, to better the nurture of the nation, and we should progress indefinitcly? Has not the assumption that nurture, not nature, is the chief factor in national progress been the key to all social legislation, to factory acts, building acts, sanitation acts, education acts, and a multitude of other enactments devised to raise the state of the people? Has not this also been the aim of all philanthropy, all charity, and most medical progress ? Have we not, in fact, largely handicapped nature by depriving inherent native ability of its special prerogative in nurture? We have burdened it also with the provision of nurture for the very stocks whose multiplication ought to be discouraged. It appears to me, therefore, that the whole of the liberal and philanthropic social reform of the past half-century and more has been based not on the hypothesis that both nature and nurture contribute to the progress of the race, but solely on the assumption that improving the environment would indefinitely raise us in the scale of nations.

I should like to impress upon you the allegory of a certain workman who found his chisel ineffectual. He hardened it, and he tempered it, and he gave it a cutting edge on the grindstone, and he finished up on the oilstone. Then he tried his chisel again and in ten minutes it was 
as ineffectual as before. Then he repeated the whole process and again the chisel failed him. Then he proceeded to 'turn up' his grindstone and replaced his oilstone by an American product, but all in vain; the chisel still refused to do efficient work. Just as he was proceeding to the process of 'hacking' his grindstone and to trying a brand-new German hone, a fellow workman suggested that the steel of his chisel might possibly be at fault. Instead, however, of proceeding to test the amount of carbon in his steel, or to try his workshop appliances on another chisel, our first workman grew angry and asserted that his colleague was neglecting all the resources of modern technology, all the advances of applied science. If hardening and tempering, if grindstone and oilstone were idle, we might as well throw aside all mechanical progress and again make our tools by chipping flints.

Now it is not so many years ago that I ventured to suggest in a lecture in a great provincial town that nature might possibly play its part as well as nurture; that elaborate schemes of primary, secondary, and higher education could only be profitable if good material existed to which they could be applied. Well, what seemed to me an obvious truth, raised a little storm ; a great municipal authority expressed regret that I had come to tell them that all they had done for technical education, all the vast sums they had spent in founding their university, were idle. He for his part would not for a moment accept such teaching. It was vain to cite the allegory of the grindstone-in that great centre of political and municipal activity the one thing that was worth considering was nurture.

Now there would be no reason to criticize this attitude, or to doubt the wisdom of much of liberal policy in the 
past, if it had been preceded by the recognition that it was and must be a tentative policy; a policy which was on its trial until we had demonstrated that nurture plays the dominant part in human progress.

A protest must, however, be raised when we find improvement of environment treated by social reformer, plilanthropist, and radical politician as the exclusive source of national progress. It is a dogma replacing knowledge, it is an illustration of what I referred to just now when I suggested that we could not tell the working classes what modern science, what modern theories of evolution, meant for human life, until we had established a new and exact sociology.

If, for a few minutes, we postpone the consideration of more exact methods of dealing with the problem of nature and nurture, we may ask one or two questions bearing on the betterment of environment as an empirical policy. In the first place I would point out that we have now had twenty to thirty years of technical instruction, university and polytechnic engineering schools, we have had a population immensely larger than in I80o to draw from. It is not the grindstone nor the oilstone which have been wanting recently. Yet has that system produced for us any four names which will stand out in the future like those of Arkwright, Watt, and the Stephensons? These men would liave profited immensely by modern technical training. But will nurture alone produce such men? If so, why is it that no Englishman of our period of technical education has been the discoverer of motorcar, submarine, or aeroplane? Can we indeed assert that, relatively to the size of our population, the period of bettered environment has led togreater provision of capable men in craftsmanship, in the arts, in science, in literature, 
or in politics? Nay, when we talk among ourselves, and not in the world's market-place, are we not rather conscious of a present dearth of national ability?-of an uncomfortable doubt as to whether we have leaders who lead, writers who can write so as to stir national feeling and national conscience, or sufficient men able to preserve by feats of enterprise and daring the old racial reputation for endurance and strength? If we look back on the more than fifty years during which the betterment of nurture has been our chief policy, can we honestly assert that the nation has grown-relatively to other nationsin its number of able men of all types, in its power of action, in its self-control, in its enterprise and its originality? Yet I do not think there is any single nation which since 1840 has so continuously and successfully worked at improving environment as our own country. Might we not on the basis of such doubts legitimately demand that the problem of nurture and nature should receive closer attention; that we should not for another fifty years confine our attention to nurture?

But beyond such generalities we can point at once to whole series of cases, where the neglect of the nature factor, the blind belief in nurture, is leading to immediate national deterioration. I will illustrate what I mean by drawing your attention to the following pedigrees :-

My first pedigree ${ }^{1}$ is one of congenital cataract. We start with a woman of whom all we know is that she was blind in old age; when she became blind we do not know ; her two daughters became blind at forty. Of her five grandchildren only one escaped, the other four were blind by thirty. Of her fifteen great-grandchildren thirteen had cataract. Of the forty-six great-great-grandchildren, who

${ }^{1}$ Gjersing's case, Treasury of Human Inherifance, Part IV, Fig. 372. 
can be traced, twenty were already, on going to school at seven, found to be of feeble sight, several were operated on before twelve years of age, and some lost the sight of one or both eyes. From that one case we find two, four, thirteen, twenty blind or semi-blind individuals in four successive generations. Forty defective individuals in a stock still multiplying, which nature, left to herself, would have cut off at its very inception! But civilized man provided an environment wherein they could survive, marry, and multiply. In the last generation the nine families of which we have records are still incomplete, and yet they average five children apiece-a number much above the average incomplete family of the healthy and fit population. See Plate I, Fig. I.

But congenital cataract was associated in this case with fairly good physique; it not infrequently occurs associated with other degeneracies. My second pedigree $\mathbf{1}$ shows you a history of mental disease :

Ancestry of mental disease, consanguinity, with physical defect in fourth generation, and cataract of form not stated. I. I, male, died mad; I. 2, his brother, had religious mania; I. I had two female children, one normal, the other died of a nervous disease, these produce the parents of the third generation. II. I-8, a sibship of eight, of whom two males were epileptic, two females hysterical, two females tubercular, one female a religious maniac, and one male described as idiotic; he marries the normal daughter, II. 9, of I. I and has several defective children. II. Io, the other daughter of I. I bears to II. II, an 'eccentric' man, three children, of whom some are defective; she then dies of some nervous disease. III. I-4, sibship from idiot father (II. 8) and normal mother (II. 9). III. I, male, tubercular. III. 2 and 3, females, religious maniacs. III. 4, normal male, who marries III. 5, his maternal first cousin, and begets six children, of whom

${ }^{1}$ Pisenti's case, Treasury of Human Inheritance, Fig. 330: 


\section{PLATE I}

I.

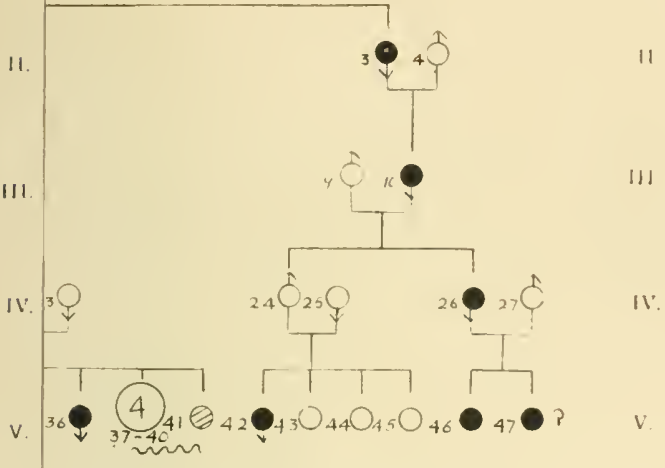

III. General. Degeneracy

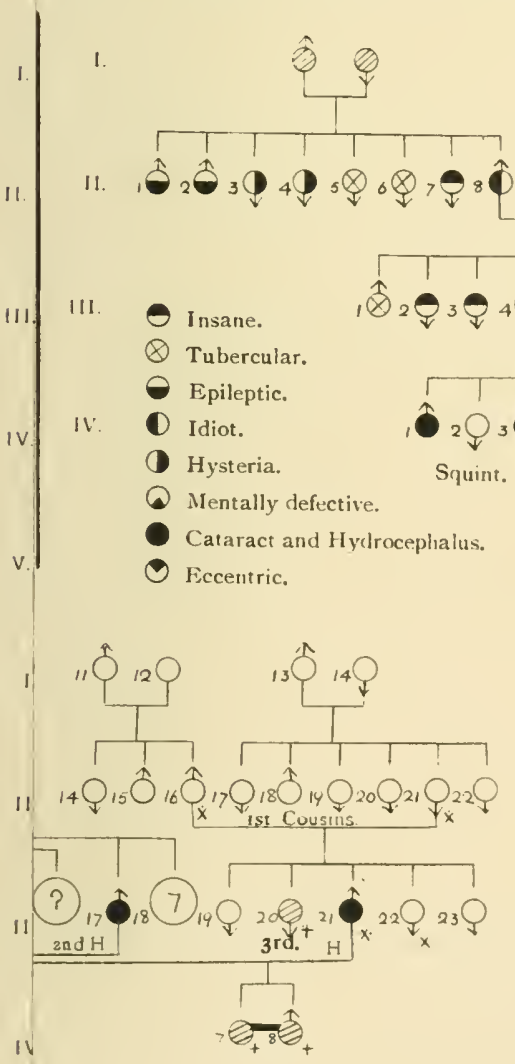

III

s.

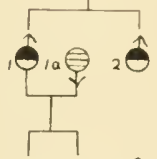



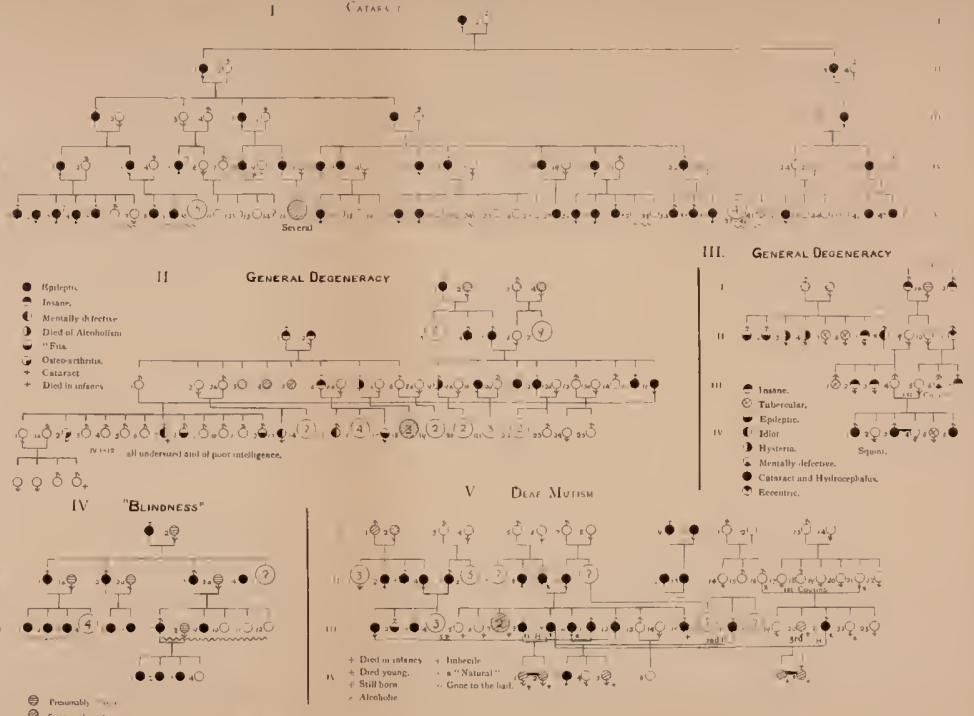

Dounably 
five are defective. III. 6, male, mentally defective. III. 7, male, alcoholic maniac. IV. I-6, family of IV. 4 and 5 , maternal first cousins, nothing being said to the discredit of their own mental state. IV. I, male, dead, shrunken congenital cataract, nystagmus, and hydrocephalus. IV. 2, female, squints. IV. 3, male, one of twins, cataract and hydrocephalus. IV. 4, female, other of twins, fairly normal. IV. 5, female, died aet. three of tubercular meningitis. IV. 6, male, cataract and hydrocephalus. See Plate I, Fig. III.

Again, we note twenty abnormals in four generations, the product of two degenerates whose right to reproduce their kind should have been challenged by society from the start, as it would have been refused a priori by nature.

In my next pedigree ${ }^{1}$ we have a single blind man leading in four generations to fifteen blind descendants :-

Form of cataract not stated. I. I, male, blind from congenital cataract, had four blind and some not blind children. II. I-5, offspring of blind father. II. I, 2, and 3 , males. II. 4 , sex not stated, blind from some kind of cataract. II. 5, not blind, sex and number not stated. III. I-4, family of seven of affected father; sex not stated, three blind of same cataract, four not affected. III. 5 and 6 , issue of affected father, both have cataract, sex not stated. III. 7-I2, issue of affected father. III. 7 , male. III. 9, sex not stated, affected. III. IO-I2, three others, sex not stated, unaffected. IV. I-4, sibship of four, due to affected father; sex not stated; three blind with cataract and inmates of a blind asylum; one not affected. See Plate I, Fig. IV.

Here is another pedigree obtained by Mr. Bishop Harman ${ }^{2}$ illustrating a combination of degeneracies through many generations :-

I. I, died in an epileptic fit. II. I, died mad in an asylum. II. 2, died mad in another asylum. II. 4 and 5 suffered

1 A. D. Williams's case, Treasury of Human Inheritance, Fig. 329.

2Personally communicated and shortly to appear in the Treasury'. 
from epilepsy and, like father, died in fits. III. I, normal, married a woman of epileptic ancestry and having herself symptoms of it. III. 3-5, died without record. III. 6 , died mad at 37 , his eldest child mentally defective and youngest has fits. III. 7 , died of alcoholism, three children of whom no record. III. 9, died of alcoholism. III. IO, II, I2, I5, and I6, epileptic, of whom III. I5 died in a fit. IV. 2, osteoarthritis, heart disease, and dropsy. IV.4, chronic blepharitis. IV. 7 , mentally defective, lamellar cataract, right eye lost. IV. 8, died in a fit. IV. Io, died of pneumonia at five weeks. IV. I2, severe convulsions. All IV. I-I2, undersized and of poor intelligence. See Plate I, Fig. II.

Lastly, I would illustrate from a subject with regard to which we have been able to obtain much data-Deafmutism. I believe that congenital deaf-mutism might be stopped in a generation. Yet what do we find? Deafmutes marrying deaf-mutes and reproducing their kind with an astonishing fertility. Provision seems to be made for these unfortunates in every way, and for cvery new generation that is born of them. Examine the pedigree ${ }^{1}$ and you will see at once how this plague spreads.

Families $D+P+R$. Nothing is known of I. I and I. 2 ; they had six children of whom three daughters, II. I, were normal, but no statement was available with regard to their descendants, if any. Another daughter, II. 2, was a deaf-mute and died. II. 3, the son, was unmarried, deaf-mute, and 'hopelessly diseased in face'. II. 4, another deaf-mute daughter, married II. 5, also a deafmute, the son of normal parents, I. 3 and I. 4, who had other five normal offspring, II. 6 . It is stated that II. 5 had no deaf-mute relatives. II. 4 and II. 5 had six children, III. I-4; III. I, deaf-mute, married III. I2, deaf-mute, but there was no issue of this marriage, III. 2 had partial hearing, III. 3 was a deaf-mute, and the other three children, III. 4, could all hear. I. 5 and I. 6 were normal and were not known to have any deaf-mute relatives. Two of their children were deaf-mutes, II. 8 and II. 9. II. 9, a mattress-maker and alcoholic, died ${ }_{1}$ Treasury of Human Inheritance, Fig. 273. 
aged 68, after a week's illness, cause unknown. He married II. IO, the congenital deaf-mute daughter of normal parents, I. 7, and I. 8. She had several brothers and sisters, II. II, all normal, whose children, III. I6, were all normal. II. Io, had ten children. Of these, III. 5, normal, died aged I 7 months. III. 6, normal, died aged four years. III. 7, were stillborn. III. 9, deaf-mute, married three times; by her first husband, III. 8, who was also deaf-mute, she had twins, IV. I-2, who died in infancy before any knowledge of deafness ascertained. Her second husband was III. I7, the deaf-mute son of deafmute parents, II. I2 and II. I3; he had seven hearing brothers and sisters. His grandparents, I. $8 a$ and I. $8 b$, were also deaf-mutes. By III. I7, III. 9 had three children, IV. $3-5$; IV. 3 was deaf-mute, IV. 4 normal, and IV. 5 died aged five months. The third husband of III. 9 was III. 2I, a deaf-mute 'natural', and by him she had twins, IV. 7-8. IV. 7 died in infancy, IV. 8 met with an accidental death, caused by the drunkenness of its mother, at the age of two months. III. IO, deaf-mute and alcoholic, in Inebriate Home for three years, married III. II, also a deaf-mute, much older than herself, but had no children. III. I2, deaf-mute, has been mentioned before. III. I3, a soldier and normal, married a normal wife, III. I4, and had a normal child, IV. 6. III. I5 was a deaf-mute imbecile unmarried. I. II and I. I2 were normal and in good circumstances; they had three normal children, II. I4-I6, but II. I6 was ruined by drink and lost all his money, he married his first cousin, II. 2I, who was also alcoholic, but not deaf-mute; her parents, I. I3 and I. I4, and her brothers and sisters, II. I7-20, and II. 22, were normal. There were five children of this marriage, III. I9-23. III. I9 was normal. III. 20, stillborn. III. 2I, a deaf-mute 'natural'. III. 22 was normal but 'went wrong', and III. 23 was normal. (Prepared in the Eugenics Laboratory.) See Plate I, Fig. v.

The marked persistence of defect that we have noted in these stocks is not, however, any peculiarity of antisocial characters. A few other pedigrees will show that desirable characters are just as closely associated 
with special stocks. I draw your attention first to one in which great musical ability (the Bach family ${ }^{1}$ ) (Plate II, Fig. VI) has been prevalent for four or five generations. In a second case (the Kemble-Siddons family ${ }^{2}$ ) we have the inheritance of great histrionic power through a number of generations, not unaccompanied by marked ability in other directions. Sec Plate II, Fig. VII. Lastly, the third pedigree gives very marked scientific ability associated with other forms of intellectual eminence in a remarkable way. See Plate II, Fig. viII.

Before I explain to you the manner in which this intensity of heredity, this force of nature, is measured, I want to emphasize once more the point from which I started, namely, that in primitive society a harsh environment undoubtedly checks the survival of all forms of physical and mental defect. Further, in civilized society all legislation which provides nurture for the feebler at the cost of the socially fitter must be detrimental to racial efficiency UNLESS (i) it is accompanied by some check to the reproduction of the unfit, or (ii) we can show that nurture rather than nature dominates the production of the mentally and physically desirable members of our community. To the first statement there can be no doubt of the answer that must be given. Every improvement of environment has lowered the death-rate and increased the net birth-rate of the unfit. But associated with this, and possibly partly due to it, has been a decreasing birth-rate of the fit. I do not propose now to enter on the details of this, but I will merely say that I regard it as demonstrated. I propose rather to turn to my second question and ask

1 Prepared by Amy Barrington.

2 Extended from a pedigree given by J. M. Bulloch in The Green Room Book, 1910, p. 643. 


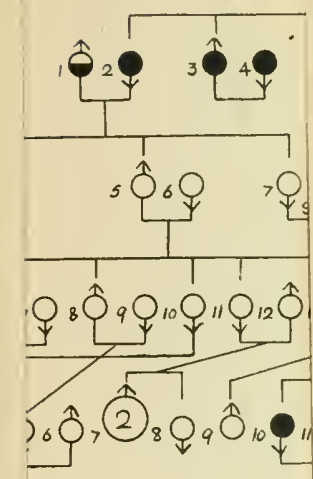

torian. $x$ Politician.

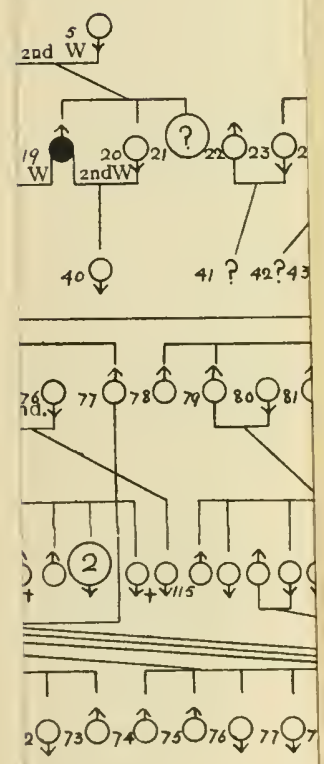




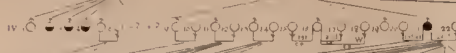

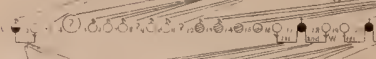

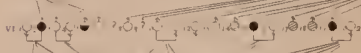

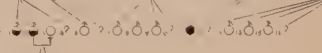
$-$

ViII intellectual Ability Science.

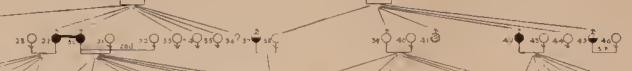

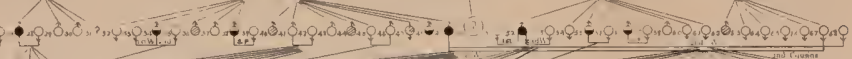

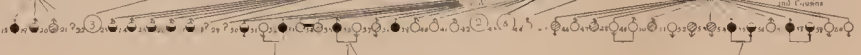

$\int_{0}^{80}$

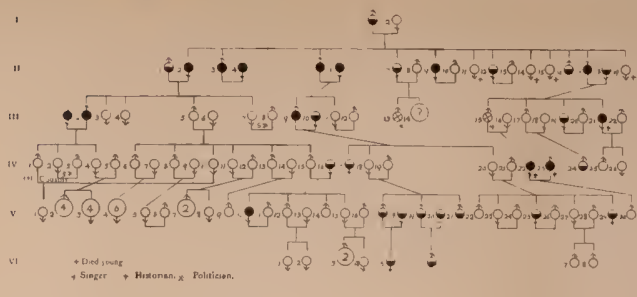

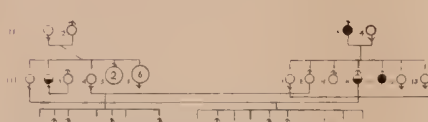

in 9

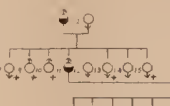

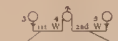

\%

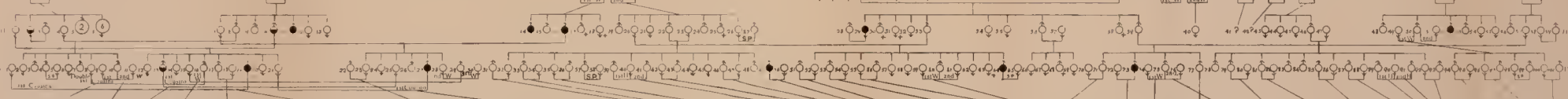
it

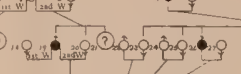

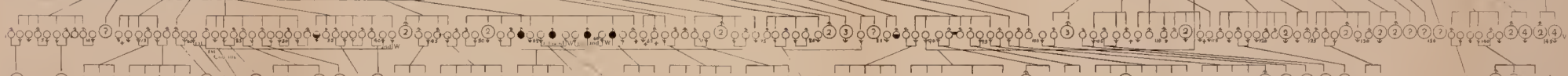

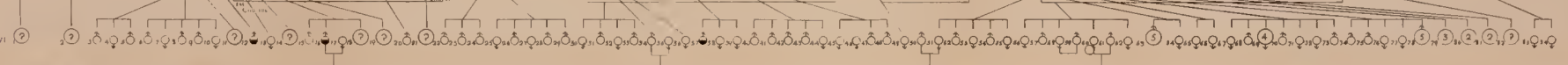


whether there is any reliable data or method by which we can compare the nature and nurture factors in man.

And, first, as to the method; that is summed up in the modern theory of statistics, and we term it the calculus of correlation. But just as it would be impossible to describe the principles of any branch of mathematical analysis in the few minutes available in a public lecture, so it is only possible to indicate to you very briefly the nature and scope of this new calculus. The fundamental difference between the categories of causation and correlation is that we replace absolute association by a weaker link. In causation $\mathrm{A}$ is always followed by $\mathrm{B}$; in correlation A may be followed by B, C, D, or E, but on the average with certain definite frequencies. Making the frequencies of $\mathrm{C}, \mathrm{D}, \mathrm{E}$, indefinitely small, we again fall back on $\mathrm{B}$ absolutely associated with $\mathrm{A}$, or our correlation passes into the causation of the physicist.

I will try and illustrate the idea as follows : Let us take a pack of cards containing hearts and other suits, and a bag of coloured balls which for simplicity we will say contains the same number of balls as the pack contains cards, and as many yellow balls as the pack contains hearts. Now suppose we take $n$ draws from the pack and in the process $x$ hearts appeared. We now take $x$ yellow balls out of the bag. It will be clear that the number of yellow balls is absolutely associated with the number of hearts. There is a complete causal relation between hearts and yellow balls and we can predict one from the other. This is the causation of the physicist, it is the perfect correlation of the biometrician; he represents it by the ratio of balls to cards, or calls the correlation unity.

Now let us modify our procedure. We will make $p$ card-drawings and if $u$ hearts occur we will draw $u$ 
yellow balls. We will now make the remainder of our card-drawings, another $n-p$, but if $x-\imath$ hearts occur, we shall not take $x-\imath$ yellow balls, but draw another $n-p$ balls at random out of the bag of balls. Let us suppose the result to be $y-u$ yellow balls. The total number of yellow balls will no longer be the same as the total number of hearts, only $u$ hearts and balls are certainly the same, $x-u$ hearts and $y-u$ balls have been obtained by perfectly independent processes, and these numbers are in no way related to each other. The absolute value of $y$, the number of yellow balls, is no longer fixed, but the average value of $y$ for a given value of $x$, the average number of yellow balls when a given number of hearts has been drawn, can easily be determined, either theoretically or experimentally. If we take the ratio of the deviation of the mean value of $y$ for a given value of $x$ from the mean value of all $y$ 's to the deviation of the given value of $x$ from the mean of all values of $x$, this ratio is constant and equal to $p / n$, i. e. to the number of cases of absolute association of hearts and balls to the total number of draws. This quantity is clearly less than unity, and becomes zero as we reduce the number of associated cases. It is termed the coefficient of correlation, and clearly measures the ratio of the number of absolutely associated contributory causes to the total number of such causes.

Now you must not go away with the idea that this illustration is the theory of correlation. It is not so, but it will give you a suggestion as to the actual nature of correlation. The theory of correlation is a calculus by which we measure the ratio of the common causal to the non-common contributory factors in two variable quantities. If we measure a character in father and son, these resemble each other in part because they are due to 
common causes - the germ-plasm of the paternal stock or the hereditary factors; they differ because they are due in part to independent causes. Correlation measures the degree in which any pair of relatives resemble each other. Again, if we take the character in any individual and any phase of his environment, we can by aid of the calculus of correlation determine to what extent that character is associated or independent of the special phase of environment. It is thus that we are now able by a single number lying between o and I to express the intensity of causal relationship between any two variable quantities. The calculus of correlation for the first time enables us adequately to approach such problems as those of nurture and nature, and to determine what weight must be given to these respective factors in our scheme of social reform.

Now I propose to draw your attention to three tables. The first gives you a rough idea of relationship between a variety of characters as measured on the scale of correlation.

TABLE I. SCALE OF CORRELATION OR MEASUREIIENT OF INTENSITY OF ASSOCIATION

\section{Causation or Perfect Correlation . . I.0o}

High Correlation 1 to $\cdot 75$.

Right and left femur in man . . . . . . . . 99

Middle finger and forearm in man . . . . . . S5 $_{5}$

Foot and forearm in man . . . . . . . . So

Middle phalanges of middle and little finger . . . . . . . 76

Considerable Correlation $\cdot 75$ TO $\cdot 50$.

Weight and stature in women

Middle finger and stature in man

Vaccination and recovery in cases of ${ }^{\circ} \cdot .66$

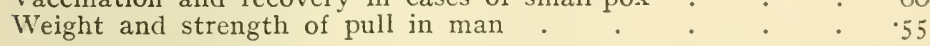

Moderate Correlation $\cdot 50$ to $\cdot 25$.

Light fluctuation and period of variable cluster stars . . 45

Bank reserve and discount rate . . . . . . . 37

Severity of attack of small-pox and years since vaccination . $\quad 3_{2}$

High barometer in Portugal and low barometer in Norway . 27 
Low Correlation $\cdot 25$ to $\cdot 00$.

Anti-typhoid inoculation and immunity

Lengths of two blood-corpuscles in the tadpole. Orbital and palate indices in Egyptian skulls

Conscientiousness and hair colour

Conscientiousness and shape of head .

Independence or Zero Correlation

$\cdot 24$

$\cdot 21$

$\cdot 12$

$\cdot 05$

.002

. 00

Table II gives you a practical estimate of the intensity of 'nature' - of the degree of the resemblance between offspring and parent.

TABLE II. STRENGTH OF NATURE.

Parental Resemblances.

Physical Characters.

Pair.

Organ.

Correlation.

Father and Son . . Stature . . . . 5 I

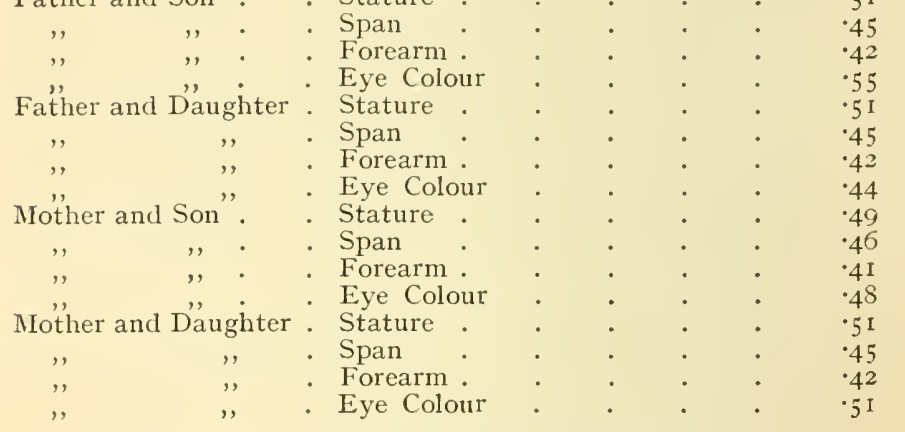

Pathological Characters.

Parent and Offspring . Pulmonary Tuberculosis (Pear-

Pulmonary Tiberculosis (Gor-

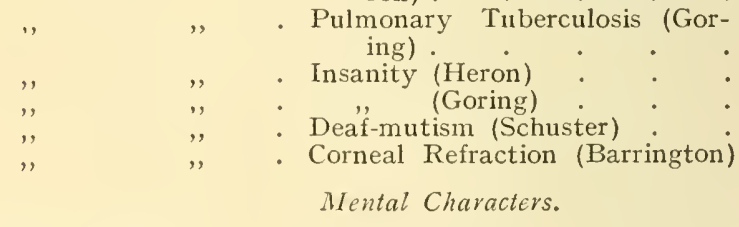
40 to 60 .43 to $\cdot 62$

.53

$\cdot 47$

$\cdot 54$

.60

Father and Son . Ability (Oxford Class Lists, Schuster) (Family Records,
Intelligence

- Intelligence (Family Records,
Pearson) 
TABLE II (continued)-

Fraternal Resemblances.

Physical Characters.

Paiy.

Organ.

Comelation.

Brother and Brot
",
",
",
Sister and Siste

Stature Organ.

5 I

.55

.49

.52

$\cdot 49$

$\cdot 59$

$\cdot 49$

.54

.56

5 I

$\cdot 45$

$\cdot 54$

.56

$\cdot 5$ I

$\cdot 55$

.53

$\cdot 44$

$\cdot 46$

$\cdot 43$

.56

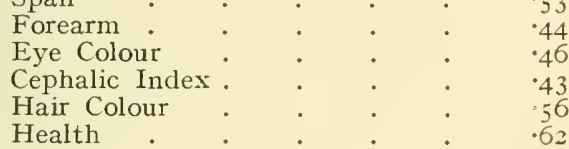

Pathological Characters.

Pairs of Siblings

Phthisis (Pearson)

Deaf-mutism (Schuster) . $\quad . \quad 73$

Mental Characters.

Brother and Brother

Sister and Sister

Brother and Sister

Pairs of Siblings

Ability

$\cdot 52$

45

$\cdot 49$

$\cdot 5 \mathrm{I}$

Temper

Handwriting

52

Mean Fraternal Correlation

$\cdot 52$

Mean 'Nature' Value

$\cdot 5 \mathrm{I}$

Table III illustrates the nurture factor in a number of cases. Several hundreds of these nurture-correlations have been worked out up to date, and they all exhibit the same state of affairs. The association of environment and of character is extremely small, and often it is impossible to say which way the environment really tends. 


\section{TABLE III. STRENGTH OF NURTURE}

Characters Dealt With.

Keenness of vision and home environment as measured by cleanliness of body and clothing

Eye disease and overcrowding .

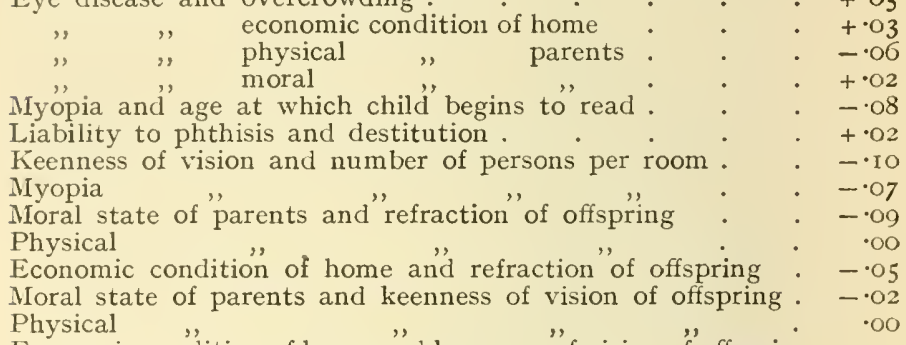

Economic condition of home and keenness of vision of offspring - - O I

Weight of child and mental capacity . . . . + +04

Stature " . . . . + + 08

Condition of "teeth and "mental capacity : . . . + +. + . +

Condition of clothing ," , (Boys) . . + 04

" " , ", " $"$ (Girls) . + + 24

State of nutrition , , , $\quad$ (Boys) . + + OI

" " " " " $"$ (Girls) . + +

Cleanliness " ", " $\quad$ (Boys) . : +•14

," , "

Glands

Tonsils

Alcoholism of parent and "weight of child

(Boys) $\quad: \quad-\circ 1$

(Girls)

$+\cdot$ I I

$+\cdot 06$

$+\cdot 06$

$-\cdot 05$

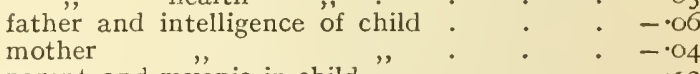

father and intelligence of child : $\quad: \quad:-06$
mother
parent and myopia in child ".

father and eye disease in child . $\quad . \quad-.08$ mother

Acuity" of vision and time out of doors

Shortsight

'Unhealthy' trade of "father and weight of child •

," ," height ", . + +

Employment of "mother and" weight of son ". $\quad \cdot \quad \cdot++{ }^{+}+{ }^{\circ}$

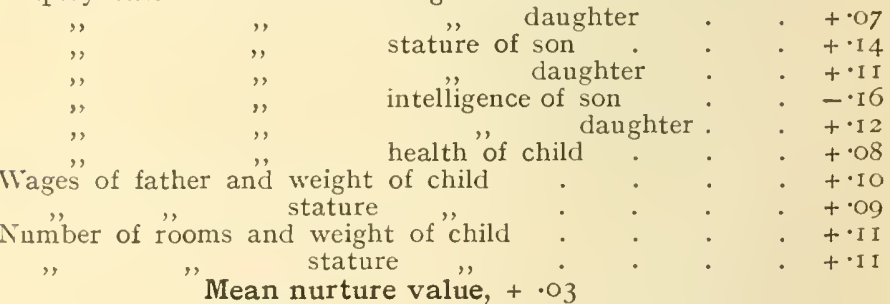

A negative sign indicates that an unfavourable condition or environment appears on the basis of the data available to indicate an improvement in the character. 
Now I will not dogmatically assert that environment matters not at all; phases of it may be discovered which produce more effect than any we have yet been able to deal with. But I think it quite safe to say that the influence of environment is not one-fifth that of heredity, and quite possibly not one-tenth of it. There is no real comparison between nature and nurture ; it is essentialiy the man who makes his environment, and not the environment which makes the man. That race will progress fastest where consciously or unconsciously success in life, power to reproduce its kind, lies with native worth. Hard environment may be the salvation of a race, easy environment its destruction. If you will think this point out in detail, I believe you will see the explanation of many great historical movements. Barbarism has too often triumphed over civilization, because a hard environment has maintained, an easy environment suspended, the force of natural selection-the power of the nature factor.

Are we then to discard the methods of civilization, to describe as worthless the whole field of liberal and social reform? I have answered that question already in my allegory. Are we to throw aside the oilstone and break up the grindstone because they cannot make bad steel into an effective tool? Surely they are necessities for the proper working of a good tool. The mistake in our social policy has been that we supposed them primary and not secondary, that we thought to advance the nation by legislation which has hampered nature, to provide nurture for the feeble, for the inherently weak stock, the steel, of which grindstone and oilstone will and can make nothing.

I do not speak lightly; there is very definite evidence 
to show that the terrible fall in our birth-rate since $\mathrm{I} 877$ has been a differential fall. It is a fall which concerns chiefly the fitter members of all classes. The fitter of all classes, from the artisan to the executive, have fewer and fewer children, but the unfit maintain their old numbers; nor is the reason hard to seek, income and wages are no longer proportional to physical or mental fitness. The man and woman who cannot afford to marry are now taxed for the education, the sanitation, the medical provision, and very often the nutrition of the offspring of those who ought not to marry. The policy of bettering the environment has been carried out regardless of the fact that it has checked the reproduction of the essentially abler and more desirable members of the community. Our ignorance of the relative intensity of nature and nurture has led us in political and philanthropic action to disregard nature in the belief that improved nurture must involve steady racial progress. If the view I have attempted to put before you to-night be a correct view, then we have spent our energies on grindstone and oilstone, when the first need was good steel.

I do not think it too late to rectify this mistake, but I believe that the change of policy required will not be an easy matter. It is not the politician we have got to educate; his opinions and his actions are in the main dictated by what the mass of the electors desire; he gives bettered environment, a larger navy, old age pensions, or franchise to women, not because he has studied what makes for or mars national welfare, but because he has studied the number of votes these grants will produce. You cannot expect him to do otherwise, when his political life depends on his plurality of votes.

The person we have to educate is the voter, and although 
my experience of the working man is somewhat out of date, I believe he is now, as thirty years ago, eager for something better than rhetoric and verbal controversy; I am not at all sure that he is not as heartily tired of the ways of politicians as any member of the educated classes, and that our recent election results signify, not that the working man has not yet made up his mind on such things as the House of Lords and Tariff Reform, but rather that he has no marked confidence in the leaders of either political party. If this possibility be in the least true, then surely the time is apt for the work of our League. I would not ask you to accept the views-far too hastily brought before you in the course of a brief lecture-without much criticism and thought; but I would ask you to bear in mind two or three fundamental propositions :-

First, that human society can now be studied by exact methods, and that it is as subject to rigid laws of change as any other group of living organisms.

Secondly, that social reform must justify itself, not by rhetoric nor by appeal to uneducated emotions, but by showing that the proposed changes will tend not only to immediate, but to future national welfare.

Thirdly, as I have specially endeavoured to illustrate, that no final solution of almost any social problem can be reached as long as we have not definitely settled whether nature or nurture is the more important factor in settling the character of the next generation.

You may be far from accepting my conclusions on this point. I make no appeal to you to do so, but I do assert that if you have not realized the magnitude of this nature versus nurture problem, if you have not seen that its study is fundamental, if you have merely shuffled it 
out of the way with the idea that the relative intensity of these two factors is of secondary importance or undeterminable; then you can give no aid to the working man on the points where he needs most education at the present critical time in our national history. But if you have formed your opinion on these points and seen their wide, if not all-dominating, bearing on national life and social progress, then your task of education will be a definite, if not an easy one. For truth at first is often an unpalatable medicine, and the sympathy which arises almost unconsciously between lecturer and audience when he voices their personal needs, is as tempting and even more dangerous than the wine of applause.

Of this point I would quote the memorable words of Seeley :-

' Think that you are the apostles, not of any political opinions, but of a method. This means that you do not want your audiences to applaud you or to agree with you, but to begin to think for themselves. Now if they begin to think for themselves, they will very probably show it by grumbling at you and arguing with you. I have sometimes had a misgiving when I have heard it said of a lecturer that the people were delighted with him; for I have said to myself, Ought they to have been delighted?'

I must apologize for quoting words so familiar to all of you, yet they come back to me after twenty-seven years with an even intensified sense of their truth, and a still higher appreciation of the spirit of the man who delivered them. Our working classes need more than ever educational help, they need more than ever some other guidance than that of the politician and the journalist; neither of these will lead them to see beyond the horizon of class-interest, will enable them to look upon the nation as an ever-changing organization susceptible of advance 
or decay, as it obeys or disobeys stern natural laws. Evolution, selection, heredity, environment, differential fertility, are not mere vague terms of biological science having no application to human life. On their right understanding depends the stability or collapse of human society in general and of our nation in particular. In I88o we talked about Darwinism and evolution as if they had merely a theoretical bearing on our philosophical and religious opinions; thirty years later we are learning that they have an immediate and intensive influence on all phases of national welfare ; and as we learn it-we fear for the future. If we can educate the working man to appreciate that the legislation of nature is more mighty than the legislation of the politician, then this League will have more than fulfilled the hope of its Founder, namely, that we should be apostles not of opinions but of method; with the knowledge of that truth will vanish most of the errors and chimeras to which, as Seeley recognized, our English politics are dangerously liable to give credence. 



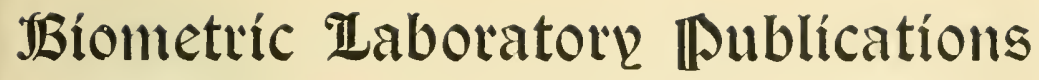

\author{
DULAU \& CO., LTD., 37 SOHO SQUARE, LONDON, W.
}

\section{DRAPERS' COMPANY RESEARCH MEMIOIRS.}

Biometric Series.

I. Mathematical Contributions to the Theory of Evolution.-XIII. On the Theory of Contingency and its Relation to Association and Normal Correlation. By KARL PEArson, F.R.S. Issued. Price 4s. net.

II. Mathematical Contributions to the Theory of Evolution.-XIV. On the Theory of Skew Correlation and Non-linear Regression. By Karl PEarson, F.R.S. Issued. Price 5s. net.

III. Mathematical Contributions to the Theory of Evolution.-XV. On the Mathematical Theory of Random Migration. By KARL PEARsox, F.R.S., with the assistance of JoHN BLAKEMAN, M.Sc. Issued. Price 5s. net.

IV. Mathematical Contributions to the Theory of Evolution.-XVI. On Further Methods of Measuring Correlation. By Karl PEARson, F.R.S. Issued. Price $4 s$, net.

V. Mathenatical Contributions to the Theory of Evolution.-XVII. On Homotyposis in the Animal Kingdom. By Ernest IVArren, D.Sc., Alice Lee, D.Sc., Edna Lea-Smith, Marion Radford, and Karl PEARSON, F.R.S.

[Shortly.

VI. Albinism in Man. By Karl Pearson, E. Nettleship, and C. H. Usher. Text, Part I, and Atlas, Part I. Issued. Price $35 \mathrm{~s}$. net.

VII. Mathematical Contributions to the Theory of Evolution.-XVIII. On a Novel Method of Regarding the Association of two Variates classed solely in Alternative Categories. By KARL PEARSON, F.R.S. Issued. Price 4 s, net.

ViII. Albinism in Man. By Karl Pearson, E. Nettleship, and C. H. Usher. Part II.

[Shortly.

\section{Studies in National Deterioration. Price 3s. net each.}

I. On the Relation of Fertility in Man to Social Status, and on the changes in this Relation that have taken place in the last 50 years. By DAvid Heron, M.A., D.Sc. Issued.

II. A First Study of the Statistics of Pulmonary Tuberculosis (Inheritance). By Karl PEarson, F.R.S. Issued.

III. A Second Study of the Statistics of Pulmonary Tuberculosis. Marital Infection. By Ernest G. POPE, revised by Karl Pearson, F.R.S. With an Appendix on Assortative Mating by Ethel M. Elderton. Issued.

IV. The Health of the School-Child in relation to its Mental Characters. By Karl Pearson, F.R.S.

[Shortly.

V. On the Inheritance of the Diathesis of Phthisis and Insanity. A Statistical Study based upon the Family History of I,500 Criminals. By Charles Goring, M.D., B.Sc. Issued.

VI. A Third Study of the Statistics of Pulmonary Tuberculosis. The Mortality of the Tuberculous and Sanatorium Treatment. By IV. P. Elderton, F.I.A., and S. J. Perry, A.I.A. Issued.

VII. On the Intensity of Natural Selection in Man. By E. C. Srow, D.Sc. Issued.

VIII. On the Correlation of Fertility with Social Value. A Co-operative Study. Just ready. 


\section{DRAPERS' COMPANY RESEARCH MEMOIRS (cont.).}

\section{Technical Series.}

I. On a Theory of the Stresses in Crane and Coupling Hooks with Experimental Comparison with Existing Theory. By E. S. ANDREws, B.Sc. Eng., assisted by KarL Pearson, F.R.S. Issued. Price $3 s$.

II. On some Disregarded Points in the Stability of Masonry Dams. By L. W. Atcherley, assisted by Karl Pearson, F.R.S. Issued. Price $3 s .6 d$.

III. On the Graphics of Metal Arches with special reference to the Relative Strength of Two-pivoted, Three-pivoted and Built-in-Metal Arches By L. W. Atcherley and Karl Pearson, F.R.S. Issued. Price $6 s$.

IV. On Torsional Vibrations in Axles and Shafting. By KARL Pearson, F.R.S. Issued. Price $6 s$.

V. An Experimental Study of the Stresses in Masonry Dams. By KARL Pearson, F.R.S., and A. F. Campbell Pollard, assisted by C. W. Wheen, B.Sc. Eng., and L. F. Richardson, B.A. Issued. Price $7 s$.

VI. On a Practical Theory of Elliptic and Pseudo-elliptic Arches, with special reference to the ideal Masonry Arch. By KarL PEarson, F.R.S., IV. D. Reynolds, B.Sc. Eng., and W. F. Stanton, B.Sc. Eng. Issued. Price $4 s$.

Completed sets may be purchased at 25s. nct.

\section{Published by the Cambridge University Press}

\section{BIOMETRIKA}

\section{A JOURNAL FOR THE STATISTICAL STUDY OF BIOLOGICAL PROBLEMS}

Founded by W. F. R. Weldon, Francis Galton and Karl Pearson (Editor).

Vol. IX. Parts I and II. Just ready.

I. On the Probable Errors of Frequency Constants, Part II. Editorial.

II. The Relationship between the Weight of the Seed planted and the Characteristics of the Plant produced. By J. ArTHUR HARris.

III. On the Probable Error of a Coefficient of Correlation as found from a Fourfold Table, by KarL PEARson.

IV. Multiple Cases of Disease in the same House. By Karl PEarson.

V. A Study of the Variations in the Female Pelvis. By Arthur Brewster EMMONS.

VI. The Intensity of Natural Selection in Man. By E. C. Snow.

VII. On Errors of Random Sampling. By M. Greenwood, Junr.

VIII. On the Probable Error of the Correlation Coefficient to a Second Approximation. By H. E. SOPER.

IX. On the Measurement of the Influence of "Broad Categories " on Correlation. By Karl Pearson.

X. Bibliography of Current Literature, Biometry and Eugenics, Nos, I-362.

XI. On Theories of Association. By Karl Pearson and David Heron.

Miscellanea (a) On the Hereditary Character of General Health. By ETHEL M. Elderton. (b) Note on the Honduras Piebald (with Four Plates). By Karl Pearson. (c) The Correction to be made to the Correlation Ratio for Grouping. By Student. (d) Selection and Intermediates in Bacillus coli. By Leonard Keene Hirschberg. 


\title{
Eugenícs $\mathfrak{L} a b o r a t o r p ~ \mathbb{P u b l i ́ c a t i o n s ~}$
}

\author{
DULAU \& CO., LTD., 37 SOHO SQUARE, LONDON, W.
}

\section{MEMOIR SERIES.}

I. The Inheritance of Ability. By Edgar Schuster, M.A., D.Sc., First Galton Research Fellow, and Ethel M. Elderton, Galton Scholar. Issued. Price 4s. net.

II. A First Study of the Statistics of Insanity and the Inheritance of the Insane Diathesis. By David Heron, M.A., D.Sc., Second Galton Research Fellow. Issued. Price 3s, net.

III. The Promise of Youth and the Performance of Manhood. By EDGAR Schuster, M.A., D.Sc., First Galton Research Fellow. Issued. Price 2s. 6d. net.

IV. On the Measure of the Resemblance of First Cousins. By Ethel MI. Elderton, Galton Rescarch Scholar, assisted by KarL PEarson, F.R.S. Issued. Price 3s. 6d. net.

V. A First Study of the Inheritance of Vision and of the Relative Influence of Heredity and Environment on Sight. By AMY BARRINGTON and Karl Pearson, F.R.S. Issued. Price 4s. net.

VI. Treasury of Human Inheritance (Pedigree of physical, psychical, and pathological Characters in Man). Parts I and II (double part). (Diabetes insipidus, Split-Foot, Polydactylism, Brachydactylism, Tuberculosis, Deaf-Mutism, and Legal Ability.) Issued. Price I 4 s. net.

VII. The Influence of Parental Occupation and Home Conditions on the Physique of the Offspring. By Ethel M. Elderton, Galton Research Scholar. Shortly.

VIII. The Influence of Unfavourable Home Environment and Defective Physique on the Intelligence of School Children. By David HERON, M.A., D.Sc., Second Galton Research Fellow. Issued. Price 4s. net.

IX. The Treasury of Human Inheritance (Pedigrees of physical, psychical, and pathological Characters in Man). Part III. (Angioneurotic Oedema, Hermaphroditism, Deaf-Mutism, Insanity, Commercial Ability.) Issued. Price 6s. net.

$\mathrm{X}$. The Influence of Parental Alcoholism on the Physique and Intelligence of the Offspring. By ETHEL M. ELDERTON, assisted by KARL Pearson. Issued. Second Edition. Price 4 s, net.

XI. The Treasury of Human Inheritance (Pedigrees of physical, psychical, and pathological Characters in Man). Part IV. (Cleft Palate, Hare-Lip, Deaf-Mutism, and Congenital Cataract.) Issued. Price Ios. net.

XII. The Treasury of Human Inheritance (Pedigrees of physical, psychical, and pathological Characters in Man). Parts V and VI. (Haemophilia.) Issued. Price $15 \mathrm{~s}$. net.

XIII. A Second Study of the Influence of Parental Alcoholism on the Physique and Intelligence of the Offspring. By KARL PEARSON, F.R.S., and Ethel MI. Elderton. Issued. Price 4 s. net.

XIV. A Preliminary Study of Extreme Alcoholism in Adults. By AwY BARRINGTON and KARL PEARSON, F.R.S., assisted by DAVID Heron, M.A., D.Sc. Issued. Price 4s. net.

$\mathrm{XV}$. The Treasury of Human Inheritance. Dwarfism, with 49 Plates of Illustrations and 8 Plates of Pedigrees. Issued. I 5s, net.

XVI. The Treasury of Human Inheritance. Prefatory matter and indices to Vol. I. With Frontispiece Portraits of Sir Francis Galton and Ancestry. Issued. Price 3s. net.

XVII. A Second Study of Extreme Alcoholism in Adults. With special reference to the Home-Office Inebriate Reformatory data. By David HERon, D.Sc. Issued. Price 5s, net.

XVIII. A First Report on the Condition of the People from the Standpoint of National Eugenics. Shortly. 


\section{EUGENICS LABORATORY LECTURE SERIES.}

I. The Scope and Importance to the State of the Science of National Eugenics. By KARL PEARSON, F.R.S. Issued. Third Edition. Price Is. nct.

II. The Groundwork of Eugenics. By KARL PEArson, F.R.S. Issued. Second Edition. Price Is. net.

III. The Relative Strength of Nurture and Nature. By Ethel MI. Elderton. Issued. Price Is, net.

IV. On the Marriage of First Cousins. By Ethel M. Elderton. Issued. Price is, net.

V. The Problem of Practical Eugenics. By Iiarl Pearson, F.R.S. Issued. Second Edition. Price is. inet.

VI. Nature and Nurture, the Problem of the Future. By KarL PEarson, F.R.S. Issued. Second Edition. Price Is, net.

V11. The Academic Aspect of the Science of National Eugenics. By KARL Pearson, F.R.S. Issued. Price Is, net.

Vili. Tuberculosis, Heredity and Environment. By KARL PEARson. Issued. Price is, net.

IX. Darwinism, Medical Progress and Eugenics. The Cavendish Lecture, I9I2. By Karl Pearson, F.R.S. Issued. Price is. net.

\section{QUESTIONS OF THE DAY AND OF THE FRAY.}

I. The Influence of Parental Alcoholism on the Physique and Ability of the Offspring. A Reply to the Cambridge Economists. By KarL. PEARson, F.R.S. Issued. Price is, net.

II. Mental Defect, Mal-Nutrition, and the Teacher's Appreciation of Intelligence. A Reply to Criticisms of the Memoir on "The Influence of Defective Physique and Unfavourable Home Environment on the Intelligence of School Children.' By David Heron, D.Sc. Issued. Price is. net.

III. An attempt to correct some of the Misstatements made by Sir Victor Horsley, F.R.S., F.R.C.S., and Mary D. Sturge, M.D., in their Criticisms of the Galton Laboratory Memoir : 'A First Study of the Influence of Parental Alcoholism,' \&c. By Kíarl PEarson, F.R.S. Issued. Price Is, net.

IV. The Fight against Tuberculosis and the Death-rate from Phthisis. By Ifarl Pearson, F.R.S. Issued. Price is. net.

V. Social Problems: Their Treatment, Past, Present and Future. By Karl PeArson, F.R.S. Issued. Price is, net.

VI. Eugenics and Public Health. Lecture to the York Congress of the Royal Sanitary Institute. By KARL PEARson, F.R.S. Issued. Price is. net.

Vol. I of the Treasury of Human Inheritance may now be obtained bound in buckram, price 52s. $6 d$. net. Buckram cases can be purchased at $2 s .9 d$. with impress of the bust of Sir Francis Galton. A photograph $\left(11^{\prime \prime} \times 13^{\prime \prime}\right)$ of Sir Francis Galton by the late Mr. Dew Smith can be obtained by sending a postal order for IOS. $6 d$. to the Hon. Sec. to the Laboratory. 


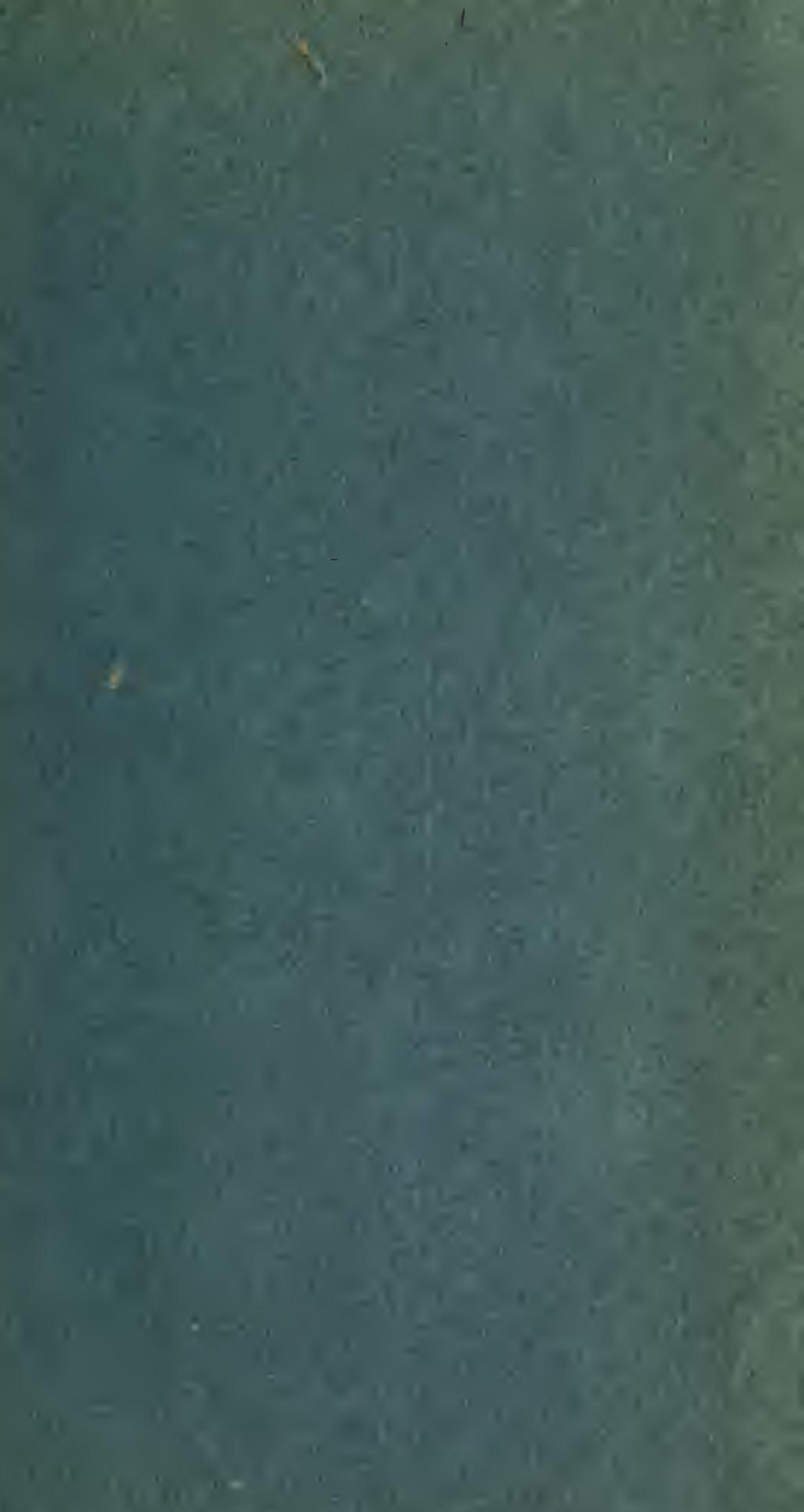






AA $001366179 \quad 8$

University of California

SOUTHERN REGIONAL LIBRARY FACILITY

305 De Neve Drive - Parking Lot 17 - Box 951388

LOS ANGELES, CALIFORNIA 90095-1388

Return this material to the library from which it was borrowed. 
